\title{
High-resolution Quaternary record of marine organic carbon content in the hemipelagic sediments of the Japan Sea from bromine counts measured by XRF core scanner
}

\author{
Arisa Seki ${ }^{*}$ (D) Ryuji Tada ${ }^{2}$, Shunsuke Kurokawa² and Masafumi Murayama ${ }^{3}$
}

\begin{abstract}
The marine organic carbon content in sediments is a useful tool for reconstructing past productivity in the ocean. Bromine has been proposed as a useful proxy for marine organic carbon, since bromine is more concentrated in marine organic matter compared to terrestrial organic matter.

Here, we present a high-resolution Quaternary record of marine organic carbon in the hemipelagic sediments of the Japan Sea obtained during Integrated Ocean Drilling Program (IODP) Expedition 346. We measured the bromine content in the sediments using an XRF core scanner (ITRAX). The total organic carbon content, total nitrogen, and stable carbon isotope values were also measured for discrete samples from the same sediments. The total organic carbon/total nitrogen ratio and the stable carbon isotope ratio of the total organic carbon are used to estimate the marine organic carbon content within the total organic carbon.

The $\mathrm{Br}$ counts and marine organic carbon content show a high correlation, which we used to construct a calibration equation of the marine organic carbon content from the $\mathrm{Br}$ counts. Using the calibration equation, we reconstructed the changes in the marine organic carbon content during the Quaternary with a time resolution of $\sim 50$ years using sediment cores from IODP Site U1424 in the east central Japan Sea. The method to estimate the marine organic carbon content from the $\mathrm{Br}$ counts measured by the XRF core scanner proposed in this paper will be a useful tool to reconstruct the organic carbon content with high resolution and high speed.
\end{abstract}

Keywords: Marine organic carbon, Japan Sea, XRF core scanner, ITRAX, Bromine, IODP, Expedition 346, Site U1424

\section{Introduction}

$\mathrm{Br}$ as a potential proxy of marine organic carbon

$\mathrm{Br}$ (Bromine) is one of the major elements in seawater. The concentration of $\mathrm{Br}$ in seawater is $6.7 \times 10^{7} \mathrm{ng} / \mathrm{L}(0.84 \mathrm{mM})$, which is the eighth highest in seawater (National Astronomical Observatory of Japan 2016). The seawater/crust concentration ratio of $\mathrm{Br}$ is second highest next to $\mathrm{Cl}$ (The Geochemical Society of Japan 2012). The average residence

\footnotetext{
* Correspondence: a_seki@shinshu-u.ac.jp

${ }^{1}$ Faculty of Science, Shinshu University, 3-1-1 Asahi, Matsumoto, Nagano

390-8621, Japan

Full list of author information is available at the end of the article
}

time of $\mathrm{Br}$ in seawater is $100 \times 10^{6}$ years (Gamo 2014). The vertical profiles of the $\mathrm{Br}$ concentration in the water column are flat, and $\mathrm{Br}$ is thus classified as a conservative element in seawater (Nozaki 1992; National Astronomical Observatory of Japan 2016). However, a recent study on the biogeochemical cycling of $\mathrm{Br}$ casts doubt on the classification of $\mathrm{Br}$ as a conservative element (Leri et al. 2010).

$\mathrm{Br}$ is known to be present in organic materials of both marine and terrestrial origin in the form of organobromine compounds (Leri et al. 2010). More than 1600 naturally occurring organobromine compounds, such as bromoalkanes, bromopyrroles, and bromophenols have 
been identified, and many of them are of marine origin (Gribble 2000). It is known that some microalgae and heterotrophic organisms produce brominated organic compounds (Gribble 1998). Bromoperoxidase enzymes, which catalyze the formation of organobromine compounds, have been found in organisms such as marine algae (red, green, and brown), bacteria, and a marine annelid (Gribble 2000). However, the structures and identities of the organobromine compounds in the deep marine sediments have not been well characterized (Berg and Solomon 2016).

In the Japan Sea, Masuzawa et al. (1988) measured the $\mathrm{Br}$ concentrations of zooplankton and found that $\mathrm{Br}$ is 3 to 20 times more concentrated in zooplankton compared to seawater. Therefore, $\mathrm{Br}$ is expected to be concentrated in the Japan Sea sediments, especially in those with high concentrations of marine organic matter.

As a result of the formation of organobromine compounds by biobromination, good correlations between the bromine content and total organic carbon (TOC) content are reported for estuarine and marine sediments (Ziegler et al. 2008; Leri et al. 2010). Since the Br concentration in seawater $(0.84 \mathrm{mM})$ is higher than that in terrestrial water (National Astronomical Observatory of Japan 2016), the $\mathrm{Br}$ content in marine organic matter is higher than that in terrestrial organic matter (Berg and Solomon 2016). The reported average $\mathrm{Br} / \mathrm{TOC}$ molar ratio for marine organic matter is $0.9-1.8 \times 10^{-3}$, while that for terrestrial organic matter is $0.06-0.3 \times 10^{-3}$ (Berg and Solomon 2016; Mayer et al. 2007; Leri et al. 2010).

Owing to the large difference in $\mathrm{Br} / \mathrm{TOC}$ ratios between marine and terrestrial organic matter, $\mathrm{Br} / \mathrm{TOC}$ ratios have been used as a proxy to distinguish organic matter of marine and terrestrial origin in estuary sediments (Mayer et al. 1981, 2007; Malcolm and Price 1984). Additionally, based on the high correlation between $\mathrm{Br}$ and TOC, $\mathrm{Br}$ is used as a proxy for TOC in deep sea sediments (Ziegler et al. 2008, 2010).

Ziegler et al. (2008) established a method to estimate the TOC content from Br profiles measured by an X-ray fluorescence (XRF) core scanner, using sediments from the Arabian Sea and a Mediterranean brine basin. They showed the usefulness of the XRF core scanner to measure the variability of $\mathrm{Br}$ and estimate the TOC with high speed and high resolution. They also pointed out that a calibration for each XRF core scanner is necessary when applying their method because the peak area counts of elements are sensitive to the XRF core scanner settings. They also suggest the possibility of estimating the marine organic carbon (MOC) content from the Br counts by removing samples where the $\delta^{13} \mathrm{C}$ values are less than $-20 \%$ (the typical value for marine organic carbon) to improve the correlation between the $\mathrm{Br}$ counts and the
TOC contents of Arabian Sea sediments. However, the relationship between the $\mathrm{Br}$ and $\mathrm{MOC}$ content has not been evaluated.

\section{XRF core scanner for high-resolution measurement}

In recent decades, XRF core scanners have become intensively used for the analysis of sediment cores in many academic fields including paleoceanographic studies (Rothwell and Croudace 2015a). The advantages of the XRF core scanner are its nondestructive measurements, high speed, and high resolution.

In previous studies, the measurement results of XRF core scanners have generally been expressed as downcore profiles of the element peak area count calculated from XRF spectra. Rarely have these peak counts been converted to the concentration of an element in sediments (Rothwell and Croudace 2015b, and references therein). This fact is because measurement by an XRF core scanner is a nondestructive method that can analyze half-round cores or u-channels directly; thus, the result is easily affected by the sediment surface condition or water content of the sediments (Croudace et al. 2006; Kido et al. 2006; Weltje and Tjallingii 2008; Weltje et al. 2015). Therefore, the data processing is more complicated even though the measurement itself is simple and easy. Some studies have made efforts to construct calibration equations to calculate the concentrations of elements from their peak area counts, but these efforts have had limited success, and XRF core scanner measurements are generally used in a qualitative way.

The ITRAX XRF core scanner is one of the most popular XRF core scanners and is manufactured and sold by COX Analytical Systems (Croudace et al. 2006; Rothwell and Croudace 2015a). Owing to the flat-beam techniques developed for the ITRAX core scanner, it has advantages for high-resolution measurement, with a highest resolution of $0.2 \mathrm{~mm}$. Since XRF measurements using the ITRAX are conducted under the ordinary atmospheric environment, elements lighter than $\mathrm{Al}$ cannot be measured because the absorption effect of X-rays by air is more significant for the lighter elements. Although the organic carbon content in sediments is important for many paleoceanographic studies, the organic carbon cannot be measured by XRF core scanners.

\section{Aim of this study}

In this study, the TOC, total nitrogen (TN), and organic matter $\delta^{13} \mathrm{C}$ of selected discrete samples taken from IODP Expedition 346 Site U1424 are measured and compared with the $\mathrm{Br}$ counts measured by the ITRAX $\mathrm{XRF}$ core scanner to evaluate the possibility of estimating MOC contents from $\mathrm{Br}$ counts in the Japan Sea sediment. Based on the results obtained, the downcore organic carbon variability in the Japan Sea sediments will 
be reconstructed at Site U1424 to demonstrate the usefulness of the method.

\section{Oceanographic settings}

Oceanographic and geological settings

The Japan Sea is a semiclosed marginal sea located along the northwest margin of the Pacific Ocean. The sea is connected with the surrounding seas through four shallow channels, the Tsushima Strait (sill depth $\sim 130 \mathrm{~m}$ ), the Tsugaru Strait (sill depth $\sim 130 \mathrm{~m}$ ), the Soya Strait (sill depth $\sim 55 \mathrm{~m}$ ), and the Mamiya (Tatar) Strait (sill depth $\sim 15 \mathrm{~m}$ ) (Fig. 1). The average depth of the Japan Sea is more than $1600 \mathrm{~m}$, with a maximum depth of more than $3700 \mathrm{~m}$ (National Astronomical Observatory of Japan 2016). The Japan Sea is composed of three basins, the Japan Basin $(\sim 3800 \mathrm{~m})$, Yamato Basin ( $3000 \mathrm{~m})$, and Tsushima (Ulleung) Basin ( $2600 \mathrm{~m})$, divided by the Yamato Rise (Gamo 2016; Fig. 1).

At present, the Tsushima Warm Current (TWC) is the only current flowing into the Japan Sea through the

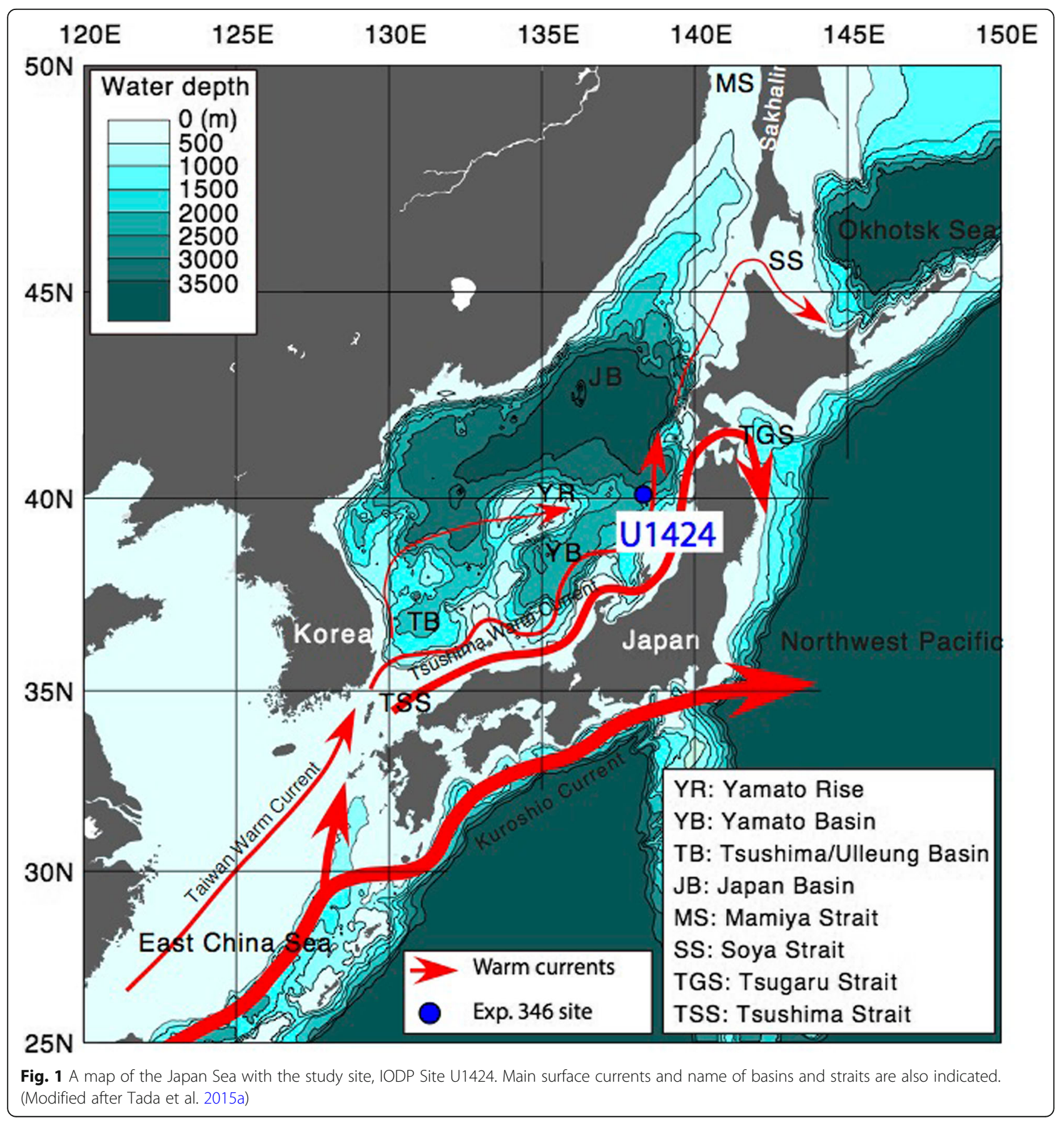


Tsushima Strait. The TWC is composed of two components, the Kuroshio Warm Current (KWC) and the Taiwan Warm Current (TWWC). The TWC originates from the KWC that flows into the Japan Sea through the southern channel, whereas the TWC originates from the TWWC flows into the Japan Sea through the northern channel of the Tsushima Strait. The TWWC flows from the South China Sea into the East China Sea (ECS), and then flows northeastward on the ECS shelf where it is mixed with river water supplied from the continent to become lower in salinity and higher in nutrients compared to the KWC flowing northeastward in the Okinawa Trough. Therefore, the surface water salinity in the Japan Sea is easily influenced by the salinity of the TWWC, which, in turn, is affected by the fresh water flux from the continent (Yanagi 2002), and the relative contributions of the TWWC and the KWC to the influx into the Japan Sea.

The modern Japan Sea produces its own deep water called the Japan Sea Proper Water (JSPW), which is characterized by a low potential temperature of $0-1{ }^{\circ} \mathrm{C}$ and high oxygen content $(200-300 \mu \mathrm{mol} / \mathrm{kg})$ throughout the deeper (> $200 \mathrm{~m}$ ) part of the Japan Sea (Gamo et al. 2014; Gamo 2016). The dissolved oxygen levels in the Japan Sea deep water are more than $200 \mu \mathrm{mol} / \mathrm{kg}$ in all three basins, and this value is higher than that in the Northwestern Pacific at the same latitude ( $150 \mu \mathrm{mol} \mathrm{kg} \mathrm{kg}^{-1}$ ) (Gamo et al. 2014). The potential temperature deeper than $2000-2500 \mathrm{~m}$ is uniform in all three basins with $<0.001{ }^{\circ} \mathrm{C}$ fluctuations, suggesting active vertical convection in the deep water (Gamo and Horibe 1983; Gamo et al. 2014). The current that flows along the western margin of the Japan Sea is cooled by the winter monsoon wind and the JSPW is formed especially in the area off Vladivostok where strong northwesterly winter monsoon winds are focused because of a topographic effect due to a mountain gap.

Since the sill depths of the modern straits are shallow $(<130 \mathrm{~m})$ and the tectonic influences are minimal, especially in the Tsushima Strait (Itaki 2016), sea level changes should be the major factor that controls the paleoceanographic conditions of the Japan Sea during the Quaternary (Tada et al. 1999). During the Last Glacial Maximum (LGM), when the sea level dropped to around $-120 \mathrm{~m}$, the surface water inflow from the Tsushima Strait dramatically decreased, and the sea became a closed system (Tada et al. 1999). The surface water salinity in the sea also decreased due to the excess precipitation plus fresh water inflow from the surrounding rivers over evaporation (Matsui et al. 1998). Consequently, the sea became stratified and the deep water became euxinic because the production of the dense deep water was reduced due to the low-salinity surface water (Tada et al. 1999).

The Japan Sea is also characterized by its low nutrient content (Yanagi 2002; Tada 2012). In the modern Japan Sea, the phosphorus content in the JSPW is low $(2.3 \mu \mathrm{M})$, and the residence times of phosphorus and nitrogen are short (2.2 years and 1.6 years in the uppermost $200 \mathrm{~m}$, respectively) (Yanagi 2002, Tada 2012). The phosphorous budget in the Japan Sea reveals that the phosphorus input from the ECS through the Tsushima Strait is by far the dominant source (Yanagi 2002). However, 90\% of the phosphorus flowing into the sea via the Tsushima Strait flows out from the Tsugaru Strait in the modern Japan Sea because the subsurface water, which has a higher nutrient content than the surface water, flows out from the Tsugaru Strait, whose sill depth ( $130 \mathrm{~m}$ ) is deeper than the thermocline (Tada 2012). Thus, the nutrient budget in the Japan Sea is also thought to have been affected significantly by changes in the sill depth controlled by sea level changes (Tada 2012).

\section{Study site}

In the summer of 2013, the Integrated Ocean Drilling Program (IODP) Expedition 346 "Asian Monsoon" drilled hemipelagic sediments at seven sites in the Japan Sea (Tada et al. 2015a). Among the seven sites, sediments recovered from Site U1424 (water depth $2808 \mathrm{~m}$ ) are selected for this study.

Site U1424 is located $\sim 150 \mathrm{~km}$ to the west of northern Honshu Island and $\sim 200 \mathrm{~km}$ to the southwest of the Tsugaru Strait $\left(40^{\circ} 11.40^{\prime} \mathrm{N}, 138^{\circ} 13.90^{\prime} \mathrm{E}\right)$, close to the boundary of the Japan Basin and Yamato Basin, with a water depth of $2808 \mathrm{~m}$ (Fig. 1; Tada et al. 2015c).

The hemipelagic sediments of the Japan Sea are known to have distinct alternations of dark and light layers (e.g., Tada et al. 1999; Tada 2004). During IODP Expedition 346, these dark and light layers were recovered at six sites in the Japan Sea at water depths deeper than $900 \mathrm{~m}$ (Tada et al. 2015a). The deposition of dark and light layers started at approximately $2.6 \mathrm{Ma}$ (million years ago) and became increasingly distinct at approximately $1.45 \mathrm{Ma}$ (Tada et al. 2015a; Tada et al. 2018). Distinct dark layers have been correlated among the six sites (Irino et al. 2018), and their deposition was synchronous basinwide, suggesting that the Japan Sea has been acting as a single system responding to climatic-oceanographic change in climatic-tectonic coupling in Asia throughout the Quaternary (e.g., Tada et al. 2016: Clift 2017).

Three holes were drilled at Site U1424 to recover a continuous sequence of sediments. The sediments back to $5 \mathrm{Ma}$ were continuously recovered. These mainly 
consist of clay and diatom ooze, with a minor component of volcaniclastic materials (Tada et al. 2015c).

Splice intervals were defined onboard, and a continuous composite column made of each splice interval was constructed. The depth scale of this composite column is expressed as "CCSF-D (m)" (Tada et al. 2015b). The splice intervals were further revised after the cruise and the new depth scale for U1424 is called "U1424 CCSF-D_Patched_rev20170308 (m)" (Irino et al. 2018). The difference between the shipboard depth scale (CCSF-D) and the new depth scale is less than $1.5 \mathrm{~m}$ throughout the splice (Irino et al. 2018). The new depth scale is employed in this study unless otherwise noted. The thickness of the Quaternary sediment is approximately $90 \mathrm{~m}$ based on the shipboard age model (Tada et al. 2015c) and $\sim 83 \mathrm{~m}$ based on the revised age model described below (Tada et al. 2018). Since this site is at the same location as Ocean Drilling Program (ODP) Site 794, the sediment sequence was correlated with ODP Site 794 cores (Irino et al. 2018).

One reason to choose Site U1424 is because no sediment disturbance (such as slumps) or hiatus is observed at this site (Tada et al. 2015c). In addition, the color alternations of dark and light layers are distinct at this site compared to sites drilled from shallower water depths (such as Site U1426 drilled at 903 m; Tada et al. 2015a; Irino et al. 2018). Another reason to choose Site U1424 is that a high-precision and high-resolution age model has been constructed at this site (Fig. 2; Tada et al. 2018).

In the Japan Sea hemipelagic sediments, especially the sediments deposited at a deep-water depth with

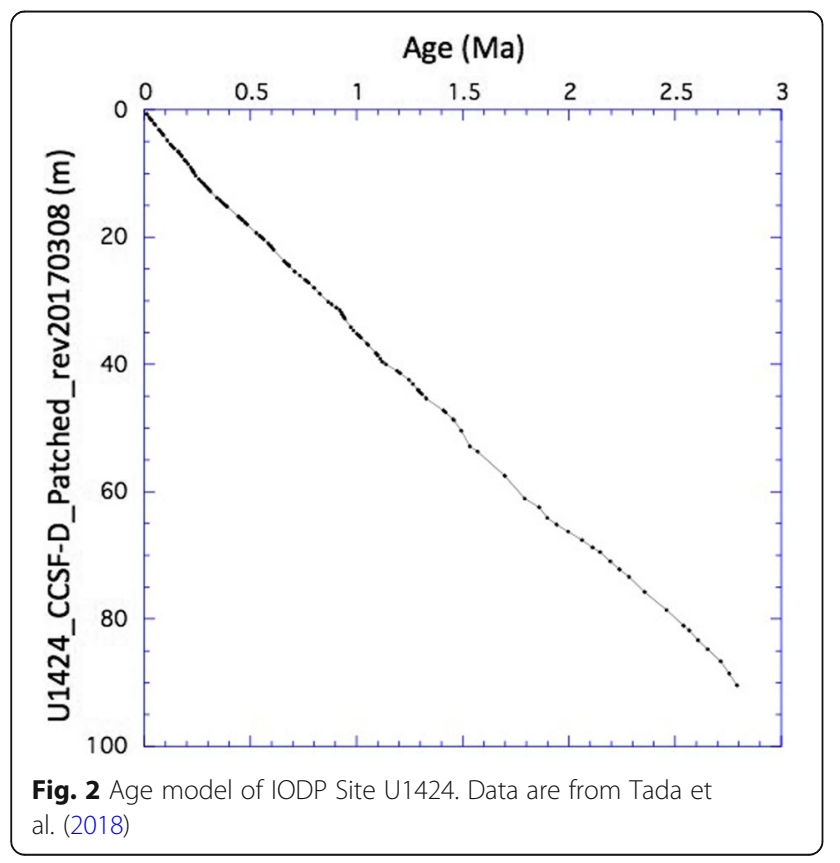

alternations of dark and light layers, foraminifer shells are not continuously found from all horizons (Tada et al. 2015c). Thus, it is difficult to construct a $\delta^{18} \mathrm{O}$ stratigraphy of foraminifer shells for the Japan Sea hemipelagic sediments. Tada et al. (2018) constructed a "LR04-tuned age model" for Site U1424 by tuning the gamma ray attenuation (GRA) bulk density of the Site U1424 composite section to the LR04 $\delta^{18} \mathrm{O}$ stack (Lisiecki and Raymo 2005) because the diatom content, which is the major reason for the density changes in the Japan Sea sediments, has been changing in association with glacial-interglacial cycles (Tada et al. 1999). Since their age model has a higher resolution and reliability covering the entire Quaternary compared to the shipboard age model, their age model (Fig. 2) is employed in this study.

\section{Methods/Experimental TOC, TN, and $\delta^{13} \mathrm{C}$ measurements}

Discrete samples of U1424 cores were subsampled from working halves in August 2016 (Table 1). Since the TOC content is different in the dark and light layers (Tada et al. 1999), every sample was obtained from the middle of either a dark or light layer and represents a 1-cm stratigraphic interval. Although tephra layers sometimes occur at Site U1424, no discrete sample contained visual tephra identified from the shipboard visual core description (VCD) and core photographs. In total, 23 samples were used in this study (Table 1).

The discrete samples were dried at $50{ }^{\circ} \mathrm{C}$ for more than 3 days and were gently ground to powder using an agate mortar. Then, 5- to 50-mg powdered samples were weighed in an $\mathrm{Ag}$ cup (dimensions: $\phi 5,9 \mathrm{~mm}$ ) and treated with $100 \mu \mathrm{l}$ of $3 \mathrm{M} \mathrm{HCl}$ for 3 days at room temperature to remove carbonate carbon. During the $\mathrm{HCl}$ treatment, the samples were stored in the Ag cups inside a desiccator with $\mathrm{NaOH}$ and $\mathrm{P}_{2} \mathrm{O}_{5}$ to remove $\mathrm{HCl}$ and $\mathrm{H}_{2} \mathrm{O}$. After the $\mathrm{HCl}$ treatment, each $\mathrm{Ag}$ cup was enfolded by a $\mathrm{Sn}$ cup (dimensions: $\phi 9,10 \mathrm{~mm}$ ) and stored in a desiccator until the measurement of the TOC, TN, and $\delta^{13} \mathrm{C}$. To estimate any carbon contamination from the $\mathrm{HCl}$, blank $\mathrm{Ag}$ cups with $\mathrm{HCl}$ treatment that were enfolded by Sn cups were also prepared.

The TOC, TN, and $\delta^{13} \mathrm{C}$ of the samples were measured by an elemental analyzer (Flash EA 1112) coupled to a ConFlo III and a Thermo Finnigan DeltaPlus Advantage isotope ratio mass spectrometer at the Center for Advanced Marine Core Research, Kochi University. Sulfanilamide was used as a standard for the TOC and TN measurements, and its analytical error $(\sigma)$ was within 0.03 wt\% for both TOC and TN. L-Alanine $\left(\delta^{13} \mathrm{C}\right.$ $=19.6 \% \pm 0.2$ ) was used as a standard for the $\delta^{13} \mathrm{C}$ measurement, and its analytical error $(\sigma)$ is $0.89 \%$. 


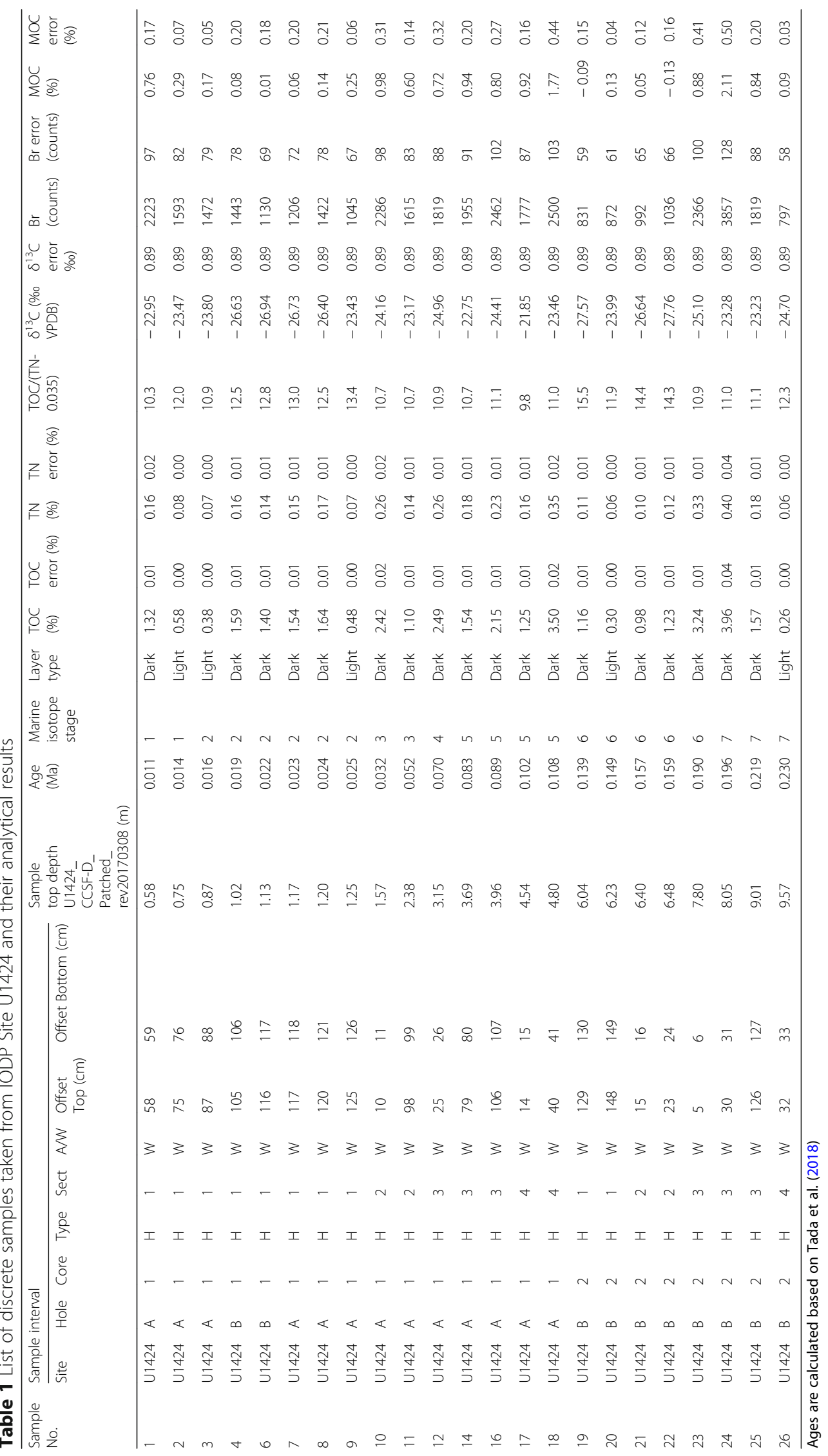


$\mathrm{Br}$ measurement using XRF core scanner (ITRAX)

Archive halves of the U1424 cores from the Quaternary intervals were measured by ITRAX, using a Mo X-ray tube with settings of $30 \mathrm{kV}, 55 \mathrm{~mA}$, a 2-mm step size, and a 10-s measurement time. Outliers in the ITRAX analytical results due to core surface disturbances (such as cracks) were eliminated after the measurement. Before the sample measurement, five repeated measurements were conducted using standard samples to evaluate the analytical precision of the measurement (Seki 2017); the analytical precision of five times repeated measurement for $\mathrm{Br}$ was determined to be $2.1 * \sqrt{ } \mathrm{N}$ (N: peak area counts; Seki 2017). To check the relationship between the $\mathrm{Br}$ counts and $\mathrm{Br}$ concentration, standard reference materials (Additional file 1: Table S1) were measured by ITRAX (Seki 2017). Since the concentration of $\mathrm{Br}$ in the standard reference material is not sufficiently high, $\mathrm{KBr}$ was added to standard reference materials and these $\mathrm{KBr}$-supplemented standard reference materials were also measured by ITRAX (Seki 2017). Based on the measurement, the $\mathrm{Br}$ counts show a high correlation with the $\mathrm{Br}$ concentrations within a range between 0 and 500 ppm (Additional file 2: Figure S1; Seki 2017). Thus, the $\mathrm{Br}$ counts can be used as a semiquantitative measure of the $\mathrm{Br}$ concentration in the sediments.

$\mathrm{Br}$ counts measured on exactly the same stratigraphic intervals as the discrete samples used for the TOC, TN, and $\delta^{13} \mathrm{C}$ measurements (Table 1) were used for comparison with the TOC, TN, and $\delta^{13} \mathrm{C}$ results. Since discrete samples represent $1-\mathrm{cm}$ intervals and the step size of the ITRAX measurement was $2 \mathrm{~mm}$, the ITRAX results from five adjacent measurements for the same stratigraphic intervals as the discrete samples were averaged (Table 1).

\section{Results and discussion}

\section{Results of TOC, TN, and $\delta^{13} \mathrm{C}$ measurements}

Table 1 shows the results of the TOC, TN, and $\delta^{13} \mathrm{C}$ measurements for discrete samples from Site U1424. In general, the TOC is high (typically 1-6\%) in dark layers and low $(<1 \%)$ in light layers (Table 1$)$. The $\mathrm{TN}$ values ranged between 0.06 and $0.4 \%$ (Table 1), and the stable carbon isotope values ranged between -20 and $-28 \%$ (Table 1 ).

It is known that the terrestrial organic matter and marine organic matter have different TOC/total organic nitrogen (TON) ratios (Lamb et al. 2006). Therefore, the TOC/TON ratio is commonly used to estimate the relative contributions of terrestrial and marine organic matter in sediments (Lamb et al. 2006). However, many paleoceanographic studies use the TOC/TN ratio instead of the TOC/TON ratio to evaluate the relative contributions because the analysis of the TN is much easier than the TON measurement (Schubert and Calvert 2001). In the Arctic Ocean, Schubert and Calvert (2001) demonstrated that a significant amount of inorganic nitrogen binds to clay minerals (especially illite) and is contained in the total nitrogen values. According to their results, inorganic nitrogen significantly affects the TOC/TN ratios (Schubert and Calvert 2001). Since the Japan Sea sediments contain significant amounts of clay, including illite (Irino and Tada 2000; Tada et al. 2015c), we investigated the possible influence of inorganic nitrogen on the TOC/TN ratio. Figure 3 shows the relationship between the TOC/TN ratio and the TOC. The TOC/TN ratio increases with the TOC, but the rate of increase gradually decreases. This relation can be explained by the presence of inorganic nitrogen binding to clay minerals. Schubert and Calvert (2001) calculated that the inorganic nitrogen content in the sediments of the central Arctic Ocean is 0.035\%, based on TON and inorganic nitrogen content measurements in sediments taken from the central Arctic Ocean. Since the reported illite contents in the Japan Sea sediment ( 14-20\%; Irino and Tada 2000) are comparable to those of the central Arctic Ocean sediments ( 20\%, Schubert and Calvert 2001), we assumed an inorganic nitrogen content in the sediment of $0.035 \%$ (the same amount as in the central Arctic Ocean) for the Japan Sea sediment used in this study. Based on this assumption, theoretical TOC/TN ratios were calculated and are shown in Fig. 3. Figure 3 reveals that the TOC/TON ratio of the U1424 samples analyzed in this study is between 9 and 16 when the correction for the inorganic nitrogen content (estimated as $0.035 \%$ ) is made. The calculated TOC/(TN-0.035) ratios have no dependency on the TOC, suggesting that the assumed content of inorganic nitrogen of $0.035 \%$ is reasonable for the U1424 samples.

The $\mathrm{C} / \mathrm{N}$ ratio and $\delta^{13} \mathrm{C}$ are both used as parameters to evaluate the relative ratio of marine versus terrestrial

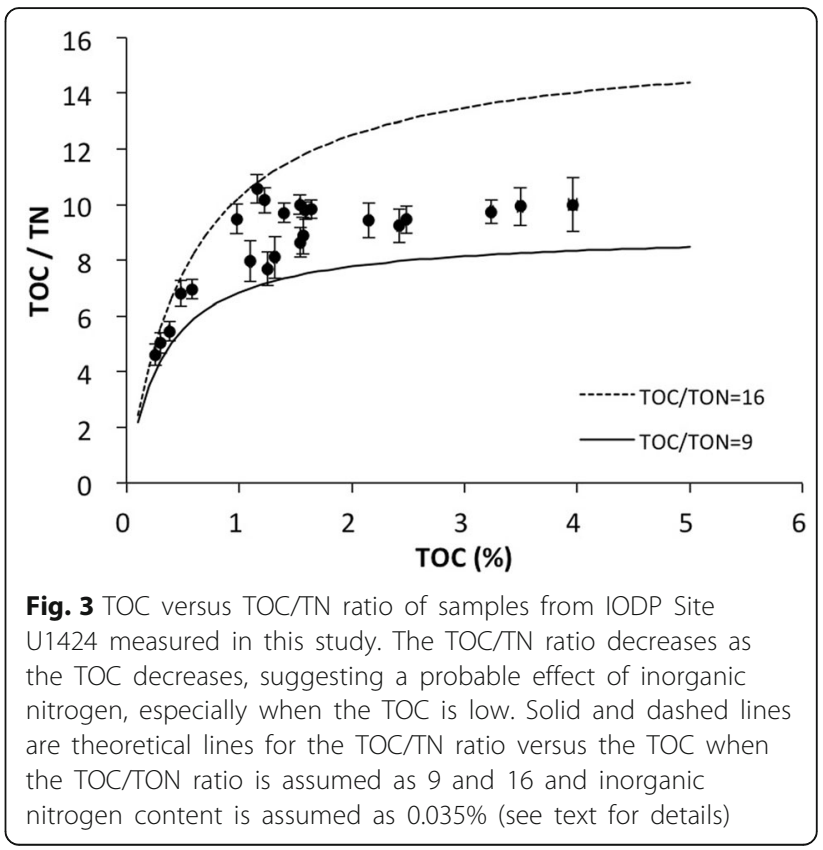


organic matter because the two parameters show distinctly different values for marine and terrestrial organic matter. Marine organic matter has a lower $\mathrm{C} / \mathrm{N}$ ratio and higher $\delta^{13} \mathrm{C}$ compared to terrestrial organic carbon (Lamb et al. 2006). The TOC/(TN-0.035) ratio and $\delta^{13} \mathrm{C}$ obtained in this study show a high correlation of $r^{2}=0.64$ (Fig. 4), with samples with a lower $\mathrm{C} / \mathrm{N}$ ratio having higher $\delta^{13} \mathrm{C}$ values. This result suggests that the organic matter in the Japan Sea sediments is a mixture of marine and terrestrial organic matter. These results suggest that both the TOC/ (TN-0.035) ratio and $\delta^{13} \mathrm{C}$ in the Japan Sea sediment are good proxies to distinguish marine from terrestrial organic matter. In this study, we use $\delta^{13} \mathrm{C}$ to calculate the percentages of marine and terrestrial organic carbon, because $\delta^{13} \mathrm{C}$ is more reliable than the $\mathrm{TOC} /(\mathrm{TN}-0.035)$ ratio, which has uncertainty in the inorganic nitrogen estimate. We assume that the $\delta^{13} \mathrm{C}$ of marine organic carbon is $20 \%$, and that of terrestrial organic carbon is $-27 \%$ (Minoura et al. 1997; Ikehara et al. 2009). Then, the MOC can be calculated as follows (Eq. 1), where "marine organic carbon fraction" means the percentage of marine organic carbon within the total organic carbon.

$$
\begin{gathered}
\operatorname{MOC}(\%)=\operatorname{TOC}(\%) \times<\text { marine organic carbon fraction }> \\
=\operatorname{TOC}(\%) \times\left(\delta^{13} C_{\text {terrestrial }}-\delta^{13} C_{\text {sample }}\right) \\
/\left(\delta^{13} C_{\text {terrestrial }}-\delta^{13} C_{\text {marine }}\right)
\end{gathered}
$$

\section{Correlation between $\mathrm{Br}$ and marine organic carbon}

The relationship between the $\mathrm{Br}$ and TOC is shown in the cross-plot of $\mathrm{Br}$ and TOC in Fig. 5. It shows a high correlation $\left(R^{2}=0.69\right)$ and a y-intercept of $739(\mathrm{Br}$ counts) (Fig. 5).

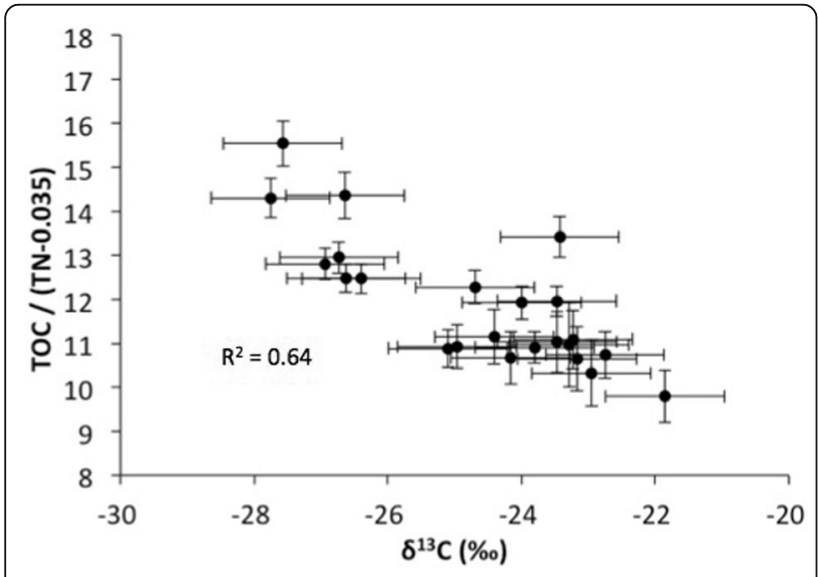

Fig. 4 Correlation between TOC/(TN-0.035) ratio and $\delta^{13} \mathrm{C}$ of the TOC for samples analyzed in this study. (TN-0.035) represents the estimated organic nitrogen content of the sediments (see text for details)
Since wet archive halves of cores were used for the ITRAX measurement, the $\mathrm{Br}$ counts include the $\mathrm{Br}$ in the interstitial water. As bromine does not accumulate in solution as dissolved organobromine compounds (Berg and Solomon 2016), the Br in organic matter and $\mathrm{Br}$ in the interstitial water should behave independently. The $\mathrm{Br}$ concentration in the interstitial water is reported from a shipboard analysis as being 0.91-1.05 ( \pm 0.03$)$ $\mathrm{mM}$ for the uppermost $10 \mathrm{~m}$ of U1424 (Tada et al. 2015b, 2015c). Using water contents measured onboard (Tada et al. 2015c) and the relationship between the $\mathrm{Br}$ counts and concentration, the contribution of the $\mathrm{Br}$ in the interstitial water to the total $\mathrm{Br}$ counts of the wet archive halves is estimated as being between 470 and 880 counts (minimum and maximum estimates). Thus, the intercept of the Br counts in Fig. 5 (739 counts) is interpreted as representing the background $\mathrm{Br}$ in the interstitial water.

Since the $\mathrm{Br}$ is mainly contained in the MOC, the relation between the $\mathrm{Br}$ and MOC (calculated from TOC and $\delta^{13} \mathrm{C}$ ) is further examined. Figure 6 shows a cross-plot of $\mathrm{Br}$ and MOC calculated from Eq. 1. For U1424, the Br counts show a better correlation with the MOC $\left(R^{2}=0.85\right)$ compared to the TOC $\left(R^{2}=0.69\right)$ (Figs. 5 and 6$)$.

Since the $\mathrm{Br}$ is mainly contained in the MOC, the calibration equation obtained from Fig. 6 is used to estimate the MOC content from the $\mathrm{Br}$ counts in this study.

$$
\begin{aligned}
& \operatorname{Br}(\text { counts })=1143 \times \operatorname{MOC}(\%)+1060 \\
& \operatorname{MOC}(\%)=(\operatorname{Br}(\text { counts })-1060) / 1143
\end{aligned}
$$

Since the analytical error of $\mathrm{Br}$ is small (less than 150 counts when the peak area count is less than 5000 counts), the error of this equation mainly comes from deviations from the regression curve in Fig. 6. The estimated error of the MOC calculation is approximately

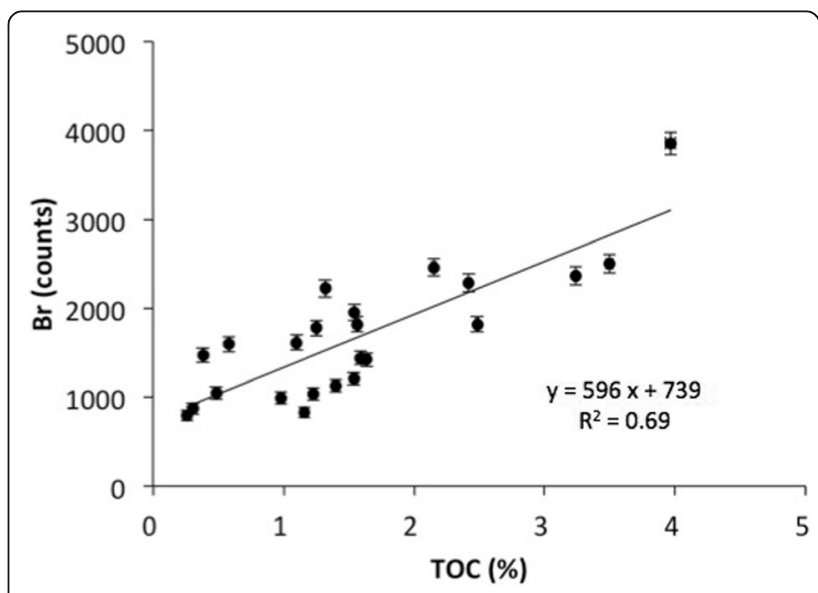

Fig. 5 Cross-plot of Br counts by XRF core scanner and TOC measured in this study 


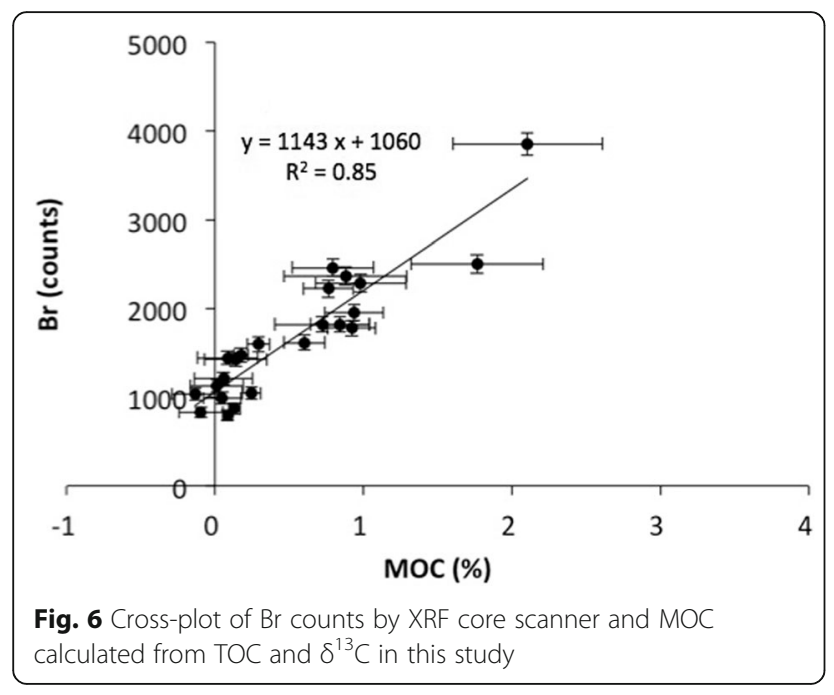

Fig. 6 Cross-plot of $\mathrm{Br}$ counts by XRF core scanner and MOC calculated from TOC and $\delta^{13} \mathrm{C}$ in this study
0.5\% (Fig. 6). It should be noted that Eqs. 2 and 3 are based on the assumption that the $\mathrm{Br}$ in terrestrial organic matter is negligible because the $\mathrm{Br} / \mathrm{TOC}$ ratio is much lower in terrestrial organic matter $\left(0.06-0.3 \times 10^{-3}\right)$ compared with marine organic matter $\left(0.9-1.8 \times 10^{-3}\right)$ (Berg and Solomon 2016; Mayer et al. 2007; Leri et al. 2010). Since analytical data on $\mathrm{Br} / \mathrm{MOC}$ ratios in marine organic matter for individual seas are not available, the applicability of the equations for the MOC calculation (Eqs. 2 and 3) for sediments from other seas (such as the open ocean) should be checked in the future. Even given the limitations described above, this method to estimate the MOC content by the high-resolution, high-speed, and nondestructive measurement of $\mathrm{Br}$ using ITRAX is a useful tool for paleoceanographic studies.

MOC variability in the Japan Sea during the Quaternary Using Eq. 3, high-resolution temporal variations of the MOC during the Quaternary were reconstructed for Site U1424 from the Br counts measured by ITRAX (Fig. 7; Additional file 3 and Additional file 4: Table

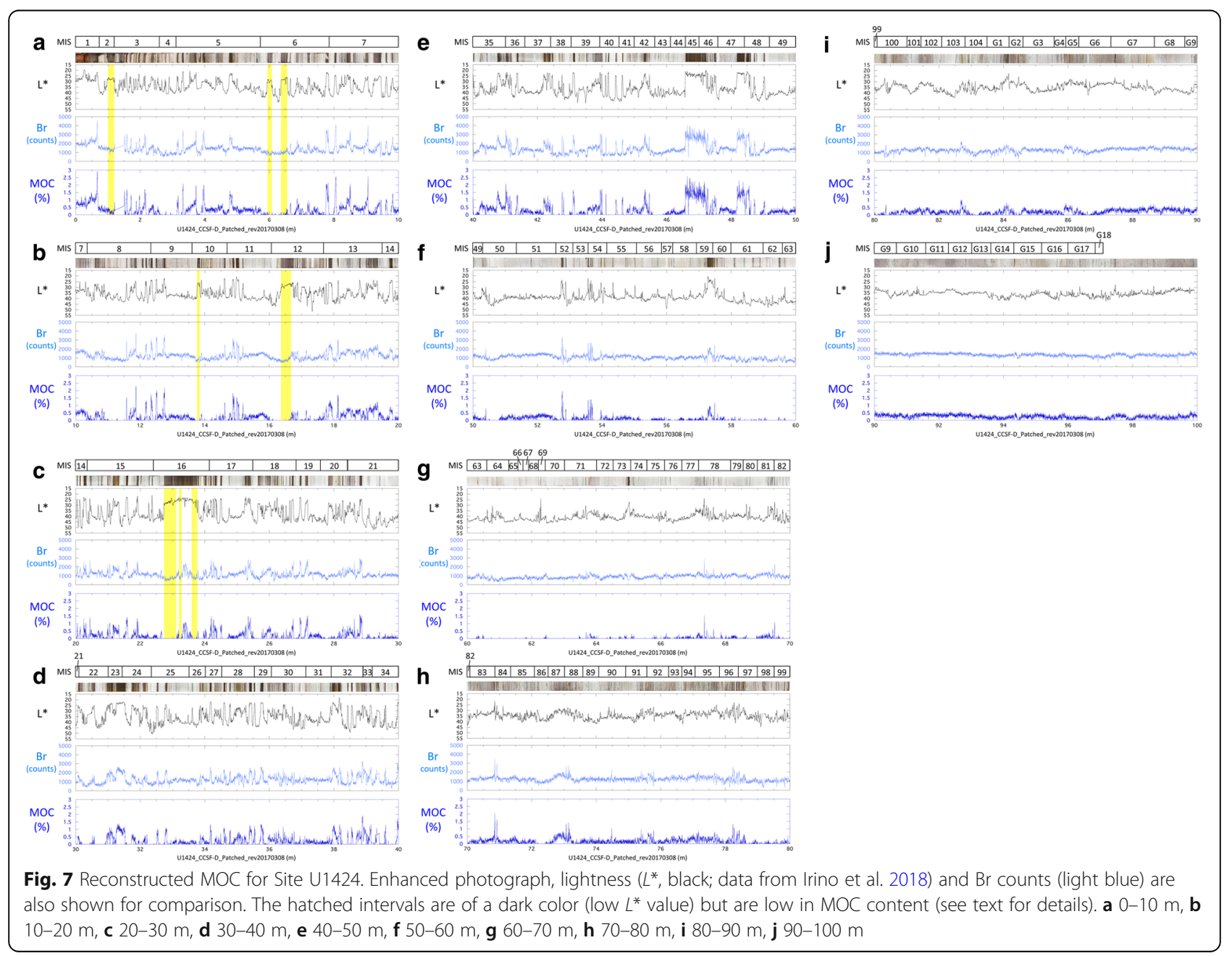


S2). Enhanced core photographs, lightness ( $L^{*}$; data from Irino et al. 2018), and Br counts measured by ITRAX are shown with the MOC in (Fig. 7; Additional file 3). The MOC values tend to be high ( $>1 \%$ ) in the dark layers (low $L^{*}$ values) and low $(<0.5 \%)$ in the light layers (high $L^{*}$ values). The concentration of the MOC in the dark layers occurs throughout the sequence, but more distinct in the uppermost $50 \mathrm{~m}$ (Fig. 7; Additional file 3), which corresponds to the last 1.5 Myr (Fig. 2; Tada et al. 2018). Below $50 \mathrm{~m}$ (before $1.5 \mathrm{Ma}$ ), dark layers are rare, and thus the low-MOC layers prevail (Fig. 7; Additional file 3).

The reconstructed MOC shows $\mathrm{cm}$-scale variability associated with the dark layers (Fig. 7; Additional file 3), which correspond to millennial-scale variability (Fig. 2; Tada et al. 2018). These millennial-scale variations are more distinct during the last $1.5 \mathrm{Myr}$ (uppermost $50 \mathrm{~m}$ (Fig. 7; Additional file 3). The MOC in the sediments reflects the surface productivity, degradation of marine organic matter within the water column and during early burial, and dilution by terrigenous and biogenic materials. Thus, the reconstructed MOC enables us to discuss possible oceanic condition changes. In the glacial period during the last $200 \mathrm{kyr}$, a millennial-scale variation in the TOC was reported (Tada et al. 1999). This millennial-scale alternation of dark and light layers in the Japan Sea sediments was proposed to reflect the East Asian summer monsoon (EASM) variability associated with Dansgaard-Oeschger cycles (Tada et al. 1999; Tada 2004). Tada et al. (1999) proposed a hypothesis on dark and light layer deposition. Namely, when the EASM became stronger during interstadials, more nutrients was provided to the Japan Sea via the Tsushima Strait, and the surface productivity in the Japan Sea was enhanced. The reconstructed MOC variability revealed that millennial-scale variability occurred not only during the last $200 \mathrm{kyr}$ but also during most of the glacial periods during the last $1.5 \mathrm{Ma}$. This suggests the occurrence of climate perturbations such as Dansgaard-Oeschger cycles in the earlier period. Since exploring the relationship between the Asian monsoon and the oceanography of the Japan Sea is important (Tada and Murray 2016), the detailed mechanism and onset timing of the millennial-scale variability of the MOC should be addressed in the future.

As described above, MOC values tend to be high $(>1 \%)$ in the dark layers throughout the sequence (Fig. 7; Additional file 3). However, there are some exceptions to the relationship between the lightness $\left(L^{*}\right)$ of the sediment and the MOC content. For example, the dark layers in the intervals of 5.9-6.1 $\mathrm{m}$ and 6.3-6.6 $\mathrm{m}$ are of a dark color (low $L^{*}$ value) but are low in MOC content (Fig. 7; Additional file 3). These layers were deposited during marine isotope stage (MIS) 6, when the eustatic sea level was more than $\sim 100 \mathrm{~m}$ lower than it is today (Tada et al. 2018). Similar trends are obvious in the layers deposited during MIS 2, 10, 12, and 16 (Fig. 7; Additional file 3). These layers have high concentrations of pyrite and are considered to have been deposited under euxinic deep-water conditions (Tada et al. 1999; Kido et al. 2007). From the results of the $\delta^{13} \mathrm{C}$ of organic carbon (sample No. 4, 6, 7, 8, 19, 21, and 22 in Table 1), these layers are also characterized by high terrestrial/marine organic matter ratios. Since organic matter is the main cause of the dark color in the Japan Sea sediments (Tada et al. 1992), $L^{*}$ has been used to estimate the TOC content in the Japan Sea because it is easy to measure compared to the conventional TOC measurement methods (Kido et al. 2007). Thus, the Br counts have an advantage over $L^{*}$ as a parameter to reconstruct the paleoproductivity. On the other hand, it may be possible to estimate the fraction of terrestrial organic carbon within the TOC using a combination of $L^{*}$ and $\mathrm{Br}$ counts, which will be tested in the future.

From the results of this study, it is clear that MOC estimation from $\mathrm{Br}$ counts measured by ITRAX has a high potential to reconstruct the paleoproductivity with high resolution and high speed and in a nondestructive way, which allows us to examine past marine productivity, the carbon cycle in the ocean, and oceanographic changes.

\section{Conclusions}

In this paper, a method to estimate the MOC content from $\mathrm{Br}$ as measured by an XRF core scanner is described. For establishing the method, the TOC, TN, and $\delta^{13} \mathrm{C}$ were measured on discrete sediment samples. The $\mathrm{TOC} / \mathrm{TN}$ ratio, which is usually used to distinguish marine organic matter from terrestrial organic matter, is significantly influenced by inorganic nitrogen bound to clay minerals. The inorganic nitrogen content of the sediment is assumed to be a constant $0.035 \%$ based on a previously reported value for sediments from the Arctic Ocean (Schubert and Calvert 2001). Both the TOC/ (TN-0.035) ratio and $\delta^{13} \mathrm{C}$ of the Quaternary Japan Sea sediments suggest a wide range of mixing of terrestrial and marine organic matter. The $\delta^{13} \mathrm{C}$ of the organic matter is used to calculate the marine organic carbon fraction, because $\delta^{13} \mathrm{C}$ is more reliable than the TOC/ (TN-0.035) ratio because the latter contains uncertainty in the inorganic nitrogen content assumption. Then, the MOC is calculated from the TOC and the marine organic carbon fraction, which is calculated from the $\delta^{13} \mathrm{C}$ value, and the calculated MOC is compared with the $\mathrm{Br}$ counts. A high positive correlation is found between the MOC and Br counts, and a calibration equation to estimate the MOC from the $\mathrm{Br}$ counts is obtained. To demonstrate the usefulness of the equation, it is applied to the Quaternary sediments of the Japan Sea. The MOC variability was reconstructed for the entire Quaternary 
sediment sequence at IODP Site U1424. The reconstructed MOC record reveals that millennial-scale variations exist since 1.5 Ma. Since the millennial-scale variations reflect climate perturbations similar to Dansgaard-Oeschger cycles, the reconstructed MOC may provide useful information to investigate past climate and oceanographic changes. $L^{*}$ is commonly used as a proxy for the TOC and used to semiquantitatively estimate the surface productivity. However, the TOC sometimes contains nonnegligible amounts of terrestrial organic carbon, the effect of which should be corrected to estimate the surface productivity. Consequently, $\mathrm{Br}$ counts are superior to $L^{*}$ if one wants to obtain more quantitative information on the surface productivity. Therefore, the MOC estimation from $\mathrm{Br}$ counts measured by ITRAX has a high potential to reconstruct the paleoproductivity with high resolution and high speed and in a nondestructive way.

\section{Additional files}

Additional file 1: Table S1. Standard reference material used in this study. (DOCX $55 \mathrm{~kb}$ )

Additional file 2: Figure S1. Relationship between $\mathrm{Br}$ counts and $\mathrm{Br}$ concentration. Results of standard reference material (Additional file 1 : Table S1) and $\mathrm{KBr}$-supplemented standard reference materials are shown. (JPG $42 \mathrm{~kb}$ )

Additional file 3: Reconstructed MOC for Site U1424. Enhanced photograph, lightness ( $L^{*}$, black; data from Irino et al. 2018) and $\mathrm{Br}$ counts (light blue) are also shown for comparison. The hatched intervals are of a dark color (low $L^{*}$ value) but are low in MOC content (see text for details). a 0-10 m, b 10-20 m, c 20-30 m, d 30-40 m, e 40-50 m, f 5060 m, g 60-70 m, h 70-80 m, i 80-90 m, j 90-100 m. (PDF 7.79 kb)

Additional file 4: Table S2. Raw data of $\mathrm{Br}$ counts and MOC content shown in Fig. 7. (XLSX 1443 kb)

\section{Abbreviations \\ EASM: East Asian summer monsoon; ECS: East China Sea; GRA: Gamma ray attenuation; IODP: Integrated Ocean Drilling Program; JSPW: Japan Sea Proper Water; KWC: Kuroshio Warm Current; LGM: Last Glacial Maximum; MIS: Marine isotope stage; MOC: Marine organic carbon; ODP: Ocean Drilling Program; TN: Total nitrogen; TOC: Total organic carbon; TON: Total organic nitrogen; TWC: Tsushima Warm Current; TWWC: Taiwan Warm Current; VCD: Visual core description; XRF: X-ray fluorescence}

\section{Acknowledgements}

We appreciate Kaz Mitake of the University of Tokyo and Minoru Ikehara, Takuya Matsuzaki, and the staff of the Kochi Core Center for laboratory assistance. We appreciate Larry Peterson and an anonymous reviewer for their constructive comments and helpful suggestions.

This research used samples provided by the International Ocean Discovery Program (IODP). This study was performed under the cooperative research program of Center for Advanced Marine Core Research (CMCR), Kochi University (16A035, 16B031).

\section{Funding}

Funding for this research was provided by JSPS KAKENHI Grant Numbers $16 \mathrm{H} 01765$ for RT and 25.9053 for AS. This work is also supported by the Sasakawa Scientific Research Grant from the Japan Science Society for AS.

\section{Authors' contributions}

RT and AS proposed the topic and conceived and designed the study. AS, SK, and MM carried out the experimental study. AS and SK analyzed the data. All authors took part in discussions about the data analysis and interpretation. AS drew the figures and wrote a draft of the manuscript. All authors read and approved the final manuscript.

Authors' information

RT was cochief scientist of IODP Expedition 346. AS and SK were students of RT.

\section{Competing interests}

The authors declare that they have no competing interests.

\section{Publisher's Note}

Springer Nature remains neutral with regard to jurisdictional claims in published maps and institutional affiliations.

\section{Author details}

${ }^{1}$ Faculty of Science, Shinshu University, 3-1-1 Asahi, Matsumoto, Nagano 390-8621, Japan. ${ }^{2}$ Graduate School of Science, The University of Tokyo, 7-3-1 Hongo, Bunkyo-ku, Tokyo 113-0033, Japan. ${ }^{3}$ Faculty of Agriculture and Marine Science, Kochi University, 200 Monobe, Nankoku-shi, Kochi 783-8502, Japan.

Received: 29 June 2018 Accepted: 19 November 2018

Published online: 07 January 2019

\section{References}

Berg RD, Solomon EA (2016) Geochemical constraints on the distribution and rates of debromination in the deep subseafloor biosphere. Geochim Cosmochim Acta 174:30-41.

Clift PD (2017) Cenozoic sedimentary records of climate-tectonic coupling in the Western Himalaya. Prog Earth Planet Sci 4:39. https://doi.org/10.1186/s40645017-0151-8.

Croudace IW, Rindby A, Rothwell RG (2006) ITRAX: description and evaluation of a new multi-function X-ray core scanner. In: Rothwell RG (ed) New techniques in sediment Core analysis, Special publication, vol 267. Geological Society, London, pp 51-63.

Gamo T (2014) Marine geochemistry. Kodansha Ltd., Japan (In Japanese).

Gamo T (2016) Tha Japan Sea-things happen in the deep sea. Kodansha Ltd., Japan (In Japanese).

Gamo T, Horibe Y (1983) Abyssal circulation in the Japan Sea. J Oceanogr Soc Jpn 39:220-230.

Gamo T, Nakayama N, Takahata N, Sano Y, Zhang J, Yamazaki E, Taniyasu S, Yamashita N (2014) The Sea of Japan and its unique chemistry revealed by time-series observations over the last 30 years. Monogr Environ Earth Planets 2(1):1-22. https://doi.org/10.5047/meep.2014.00201.0001.

Gribble GW (1998) Naturally occurring organohalogen compounds. Acc Chem Res 31:141-152.

Gribble GW (2000) The natural production of organobromine compounds. Environ Sci Pollut Res 7(1):37-49. https://doi.org/10.1065/espr199910.002.

Ikehara M, Akita D, Matsuda A (2009) Enhanced marine productivity in the Kuroshio region off Shikoku during the last glacial period inferred from the accumulation and carbon isotopes of sedimentary organic matter. J Quat Sci 24(8):848-855.

Irino T, Tada R (2000) Quantification of aeolian dust (Kosa) contribution to the Japan Sea sediments and its variation during the last $200 \mathrm{ky}$. Geochem J 34:59-93.

Irino T, Tada R, Ikehara K, Sagawa T, Karasuda A, Kurokawa S, Seki A, Lu S (2018) Construction of perfectly continuous records of physical properties for darklight sediment sequences collected during IODP expedition 346. Prog Earth Planet Sci 5:19. https://doi.org/10.1186/s40645-018-0167-8I.

Itaki T (2016) Transitional changes in microfossil assemblages in the Japan Sea from the Late Pliocene to Early Pleistocene related to global climatic and local tectonic events. Prog Earth Planet Sci 3:11. https://doi.org/10.1186/ s40645-016-0087-4

Kido Y, Koshikawa T, Tada R (2006) Rapid and quantitative major element analysis method for wet fine-grained sediments using an XRF mixroscanner. Mar Geol 229:209-225.

Kido Y, Minami I, Tada R, Fujine K, Irino T, Ikehara K, Chun JH (2007) Orbital-scale stratigraphy and high-resolution analysis of biogenic components and deep water oxygenation conditions in the Japan Sea during the last 640 kyrs using XRF microscanner. Palaeogeogr Palaeoclimatol Palaeoecol 247:32-49. https:// doi.org/10.1016/j.palaeo.2006.11.020. 
Lamb AL, Wilson GP, Leng MJ (2006) A review of coastal palaeoclimate and relative sea-level reconstructions using $\delta^{13} \mathrm{C}$ and $\mathrm{C} / \mathrm{N}$ ratios in organic material. Earth-Sci Rev 75:29-57.

Leri AC, Hakala JA, Marcus MA, Lanzirotti A, Reddy CM, Myneni SCB (2010) Natural organobromine in marine sediments: new evidence of biogeochemical Br cycling. Glob Biogeochem Cycles 24:GB4017.

Lisiecki LE, Raymo ME (2005) A Pliocene-Pleistocene stack of 57 globally distributed benthic $\delta^{18} \mathrm{O}$ records. Paleoceanography 20(1):PA1003. https:// doi.org/10.1029/2004PA001071.

Malcolm SJ, Price NB (1984) The behaviour of iodine and bromine in estuarine surface sediments. Mar Chem 15:263-271.

Masuzawa T, Koyama M, Terazaki M (1988) A regularity in trace element contents of marine zooplankton species. Mar Biol 97:587-591. https://doi.org/10.1007/ BF00391056.

Matsui H, Tada R, Oba T (1998) Low-salinity isolation event of the Japan Sea in response to eustatic sea-level drop during the LGM: reconstruction based on salinity-balance model. Quatern Res (Daiyonki-kenkyu) 37:221-233 (in Japanese with English abstract).

Mayer LM, Macko SA, Mook WH, Murray SM (1981) The distribution of bromine in coastal sediments and its use as a source indicator for organic matter. Org Geochem 3:37-42.

Mayer LM, Schick LL, Allison MA, Ruttenberg KC, Bentley SJ (2007) Marine vs. terrigenous organic matter in Louisiana coastal sediments: the uses of bromine:organic carbon ratios. Mar Chem 107:244-254.

Minoura K, Hoshino K, Nakamura T, Wada E (1997) Late Pleistocene-Holocene palcoproductivity circulation in the Japan Sea: sea-level control on $\delta^{13} \mathrm{C}$ and $\delta^{15} \mathrm{~N}$ records of sediment organic material. Palaeogeogr Palaeoclimatol Palaeoecol 135:41-50.

National Astronomical Observatory of Japan (ed) (2016) Rika Nenpyo (chronological scientific tables). Maruzen Publishing Co., Ltd., Japan (In Japanese).

Nozaki Y (1992) Trace elements in sea water: their mean concentrations and North Pacific profiles. Chikyukagaku (Geochemistry) 26:25-39 (In Japanese with English abstract)

Rothwell RG, Croudace IW (2015a) Micro-XRF studies of sediment cores: a perspective on capability and application in the environmental sciences. In: Croudace IW, Rothwell RG (eds) Micro-XRF Studies of sediment cores, developments in Paleoenvironmental research 17. https://doi.org/10.1007/ 978-94-017-9849-51.

Rothwell RG, Croudace IW (2015b) Twenty years of XRF Core scanning marine sediments: what do geochemical proxies tell us? In: Croudace IW, Rothwell RG (eds) Micro-XRF studies of sediment cores, developments in Paleoenvironmental research 17. https://doi.org/10.1007/978-94-017-9849-52.

Schubert CJ, Calvert SE (2001) Nitrogen and carbon isotopic composition of marine and terrestrial organic matter in Arctic Ocean sediments: implications for nutrient utilization and organic matter composition. Deep Sea Res Part I 48:789-810.

Seki A (2017) Reconstruction of marine organic matter content in the sediments and deep-water redox condition variability of the Japan Sea during the quaternary using high-resolution XRF core scanner. Dissertation, the University of Tokyo, Tokyo.

Tada R (2004) Onset and evolution of millennial-scale variability in the Asian Monsoon and its impact on paleoceanography of the Japan Sea. Millennial-Scale Variability in the Asian Monsoon, American Geological Union, U.S.A, pp 1-16.

Tada R (2012) The Japan Sea sediments and variability of East Asian Monsoon: toward the IODP drilling of the Japan Sea and East China Sea. Quatern Res 51:151-164 (In Japanese).

Tada R, Irino T, Ikehara K, Karasuda A, Sugisaki S, Xuan C, Sagawa T, Itaki T, Kubota Y, Lu S, Seki A, Murray RW, Alvarez-Zarikian C, Exp. 346 Scientists (2018) Highresolution and -precision correlation of dark and light layers in the Quaternary hemipelagic sediments of the Japan Sea recovered during IODP expedition 346. Prog Earth Planet Sci 5:19. https://doi.org/10.1186/s40645018-0167-8

Tada R, Irino T, Koizumi I (1999) Land-ocean linkages over orbital and millennial timescales recorded in late Quaternary sediments of the Japan Sea. Paleoceanography 14(2):236-247.

Tada R, Koizumi I, Cramp A, Rahman A (1992) Correlation of dark and light layers, and the origin of their cyclicity in the Quaternary sediments from the Japan Sea. In: Pisciotto KA, Ingle JC, von Breymann J et al (eds) Proceedings of ocean drilling program scientific results, vol 127/128. Ocean Drilling Program, TX, pp 577-601.

Tada R, Murray RW (2016) Preface for the article collection "Land-Ocean linkages under the influence of the Asian monsoon". Prog Earth Planet Sci 3:24 https://doi.org/10.1186/s40645-016-0100-y.

Tada R, Murray RW, Alvarez Zarikian CA, Anderson WT Jr, Bassetti MA, Brace BJ, Clemens SC, da Costa Gurgel MH, Dickens GR, Dunlea AG, Gallagher SJ, Giosan L, Henderson ACG, Holbourn AE, Ikehara K, Irino T, Itaki T, Karasuda A, Kinsley CW, Kubota Y, Lee GS, Lee KE, Lofi J, Lopes CICD, Peterson LC, Saavedra-Pellitero M, Sagawa T, Singh RK, Sugisaki S, Toucanne S, Wan S, Xuan C, Zheng H, Ziegler M (2015a) Expedition 346 summary. In: Tada R, Murray RW, Alvarez Zarikian CA, the Expedition 346 Scientists (eds) Proc. IODP, 346. Integrated Ocean Drilling Program, College Station. https://doi. org/10.2204/iodp.proc.346.101.2015.

Tada R, Murray RW, Alvarez Zarikian CA, Anderson WT Jr, Bassetti MA, Brace BJ, Clemens SC, da Costa Gurgel MH, Dickens GR, Dunlea AG, Gallagher SJ, Giosan L, Henderson ACG, Holbourn AE, Ikehara K, Irino T, Itaki T, Karasuda A, Kinsley CW, Kubota Y, Lee GS, Lee KE, Lofi J, Lopes CICD, Peterson LC, Saavedra-Pellitero M, Sagawa T, Singh RK, Sugisaki S, Toucanne S, Wan S, Xuan C, Zheng H, Ziegler M (2015b) Methods. In: Tada R, Murray RW, Alvarez Zarikian CA, the Expedition 346 Scientists (eds) Proc. IODP, 346. Integrated Ocean Drilling Program, College Station. https://doi.org/10.2204/iodp.proc. 346.102.2015.

Tada R, Murray RW, Alvarez Zarikian CA, Anderson WT Jr, Bassetti MA, Brace BJ, Clemens SC, da Costa Gurgel MH, Dickens GR, Dunlea AG, Gallagher SJ, Giosan L, Henderson ACG, Holbourn AE, Ikehara K, Irino T, Itaki T, Karasuda A, Kinsley CW, Kubota Y, Lee GS, Lee KE, Lofi J, Lopes CICD, Peterson LC, Saavedra-Pellitero M, Sagawa T, Singh RK, Sugisaki S, Toucanne S, Wan S, Xuan C, Zheng H, Ziegler M (2015c) Site U1424. In: Tada R, Murray RW, Alvarez Zarikian CA, the Expedition 346 Scientists (eds) Proc. IODP, 346. Integrated Ocean Drilling Program, College Station. https://doi.org/10.2204/ iodp.proc.346.105.2015.

Tada R, Zheng H, Clift PD (2016) Evolution and variability of the Asian monsoon and its potential linkage with uplift of the Himalaya and Tibetan plateau. Prog Earth Planet Sci 3:4. https://doi.org/10.1186/s40645-016-0080-y.

The geochemical society of Japan (2012) Encyclopedia of chemistry in earth and space. Asakura Publishing Co., Ltd., Japan ISBN978-4-254-16057-4 C3544 (in Japanese).

Weltje GJ, Bloemsma MR, Tjallingii R, Heslop D, Röhl U, Croudace IW (2015) Prediction of geochemical composition from XRF-core-scanner data: a new multivariate approach including automatic selection of calibration samples and quantification of uncertainties. In: Croudace IW, Rothwell RG (eds) MicroXRF Studies of Sediment Cores, Developments in Paleoenvironmental Research 17. https://doi.org/10.1007/978-94-017-9849-5_21.

Weltje GJ, Tjallingii R (2008) Calibration of XRF core scanners for quantitative geochemical logging of sediment cores: theory and application. Earth Planet Sci Lett 274:423-438.

Yanagi T (2002) Water, salt, phosphorus and nitrogen budgets of the Japan Sea. $J$ Oceanogr 58:797-804.

Ziegler M, Jilbert T, de Lange GJ, Lourens LJ, Reichart GJ (2008) Bromine counts from XRF scanning as an estimate of the marine organic carbon content of sediment cores. G-cubed 9:Q05009.

Ziegler M, Lourens LJ, Tuenter E, Reichart GJ (2010) High Arabian Sea productivity conditions during MIS 13-odd monsoon event or intensified overturning circulation at the end of the mid-Pleistocene transition? Clim Past 6:63-76. 